\title{
Research on the Effect of Antioxidant Tabernaemontana catharinensis (Apocynaceae) on Erythrocytes Exposed to the Herbicide 2,4-Dichlorophenoxyacetic Acid
}

\author{
Roberta Cattaneo Horn ${ }^{1,2}$, Luana Junges ${ }^{1}$, Luana Pereira Magni ${ }^{1}$, Natacha Cossettin Mori ${ }^{1}$, \\ Gabriela Tassotti Gelatti ${ }^{1}$, Tamiris Felippin ${ }^{1}$, Ana Caroline Tissiani ${ }^{1}$, Mariana Spanamberg Mayer ${ }^{1}$, \\ Diego Pascoal Golle ${ }^{2} \&$ Isis Amaral Thums ${ }^{1}$ \\ ${ }^{1}$ Laboratório de Estresse Oxidativo, Programa de Pós-Graduação em Atenção Integral a Saúde, Universidade de \\ Cruz Alta (UNICRUZ), Campus Universitário Dr. Ulisses Guimarães, Parada Benito, Cruz Alta, RS, Brazil \\ ${ }^{2}$ Laboratório de Cultura in vitro, Mestrado Profissional em Desenvolvimento Rural, Universidade de Cruz Alta \\ (UNICRUZ), Campus Universitário Dr. Ulisses Guimarães, Parada Benito, Cruz Alta, RS, Brazil \\ Correspondence: Roberta Cattaneo Horn, Universidade de Cruz Alta (UNICRUZ), Campus Universitário Dr. \\ Ulisses Guimarães, Rod. Municipal Jacob Della Méa, km 5.6, Parada Benito, 98020-290, Cruz Alta, RS, Brazil. \\ E-mail: rcattaneo@unicruz.edu.br
}

Received: June 6, 2016

Accepted: July 12, $2016 \quad$ Online Published: August 15, 2016

doi:10.5539/jas.v8n9p128

URL: http://dx.doi.org/10.5539/jas.v8n9p128

\begin{abstract}
With the purpose of finding an alternative to mitigate the damaging effect of intoxication with 2,4-D (2,4-Dichlorophenoxyacetic acid), this research aims to determine whether Tabernaemontana catharinensis (cobrina) increases the antioxidant capacity and/or lowers the oxidative effects generated by the exposure to this herbicide. For the above purpose, blood samples were obtained from healthy volunteers. The erythrocytes were separated, exposed to the 2,4-D and treated with different concentrations of infusions of cobrina. Tests were conducted in a water bath at $37^{\circ} \mathrm{C}$ for one hour. After the analytical determinations, it was verified that, with the duration of this test, the cobrina -even containing flavonoids in its composition- increased the oxidative damages in the proteins and lipids of the erythrocytes tested.
\end{abstract}

Keywords: cobrina, characterization, pesticides, oxidative stress

\section{Introduction}

Herbicides are agrochemicals used for controling the growth of harmful, undesirable weeds, and they are intended to significantly increase crop yields (Murussi et al., 2014). Most of such compounds are little molecules that normally do not cause intrinsic toxic effects. Nevertheless, since herbicides specifically inhibit important biochemical elements or physiological ducts of the plant, they can, in many cases, cause catastrophic damage and have lethal consequences. Synthetic auxins, like, for instance, 2,4-D, are selective herbicides, that is, they are used to control determined species of weeds, and generally cause some kind of hormonal disorder (Song, 2014).

Cases of chronic or acute intoxication of farmers owing to the handling or application of this herbicide are frequently reported (Saghir et al., 2013). Its main effects are teratogenicity, genotoxicity, neurotoxicity, immunosuppression, cytotoxicity and hepatotoxicity (Bukowska et al., 2006). Furthermore, this herbicide can cause alterations in the nervous system and behavior disorders (Bortolozi et al., 2003, 2004; Garcia et al., 2004), as well as nephrotoxicity in the renal proximal tubule (Saghir et al., 2013). Therefore, although big profits are obtained by using this herbicide, it causes problems associated with its accumulation and leaves undesired sequels in non-targeted organisms.

Tabernaemontana catharinensis is a species of tree belonging to the family of the Apocynaceae. It grows in Argentina, Paraguay, Bolivia and southeast of Brazil. The infusion of this plant is used in popular medicine as an antidote to snake bites, as an analgesic for tooth pain and also as a vermifuge (Pereira et al., 2005). Furthermore, the plant has been scientifically related to such biological functions as antimicrobial, anti-herpes (Boligon et al., 2015), anticholinesterasic (Nicola et al., 2013) and antimutagenic (Guidoti et al., 2015). It should be stressed that 
Nicola et al. (2013) and Boligon et al. (2013) proved, by tests for the determination of its total antioxidazing capacity, that the plant activity favors the generation of reactive oxygen species (ROS).

In view of the above, the purpose of this research is to assess whether the infusion of leaves of cobrita has the capacity to revert the disturbances generated by the exposure to 2,4-D.

\section{Materials and Methods}

\subsection{Ethical Aspects}

This research was submitted to the Ethics Committee of the University of Cruz Alta and was approved under protocol number: 15510413.3.0000.5322.

\subsection{Cultivation and Collection of Sheets T. catharinensis}

The tree T. catharinensis was cultivated in the experimental area of the Laboratory of vegetable multiplication, University Campus of UNICRUZ- Polo Tecnológico do Alto Jacuí in Cruz Alta, located in the northwest of the state of Rio Grande do Sul. The soil is characterized as Oxisoil Typical type A moderate, medium texture (Embrapa, 2006). The climate, according to Köeppen classification, is subtropical, Cfa 2a, with rainfall evenly distributed throughout the year. The geographical coordinates are: latitude $28^{\circ} 38^{\prime} 19^{\prime \prime} \mathrm{S}$ and longitude $53^{\circ} 36^{\prime} 23^{\prime \prime} \mathrm{O}$, with an average altitude of $452 \mathrm{~m}$.

\subsection{Carachteristics of Tabernaemontana catharinensis}

The determination of total phenolic and flavonoid compounds was done with a mother infusion of Tabernaemontana catharinensis $(50 \mathrm{~g} / \mathrm{L})$, from which lower concentrations were prepared.

\subsubsection{Determination of Total Phenolic Compounds}

The determination of total phenolic compounds was performed by following the method described by Chandra and Mejia (2004), with little modifications. An infusion of $50 \mathrm{~g} / \mathrm{L}$ de lyophilized pennyroyal was diluted in distilled water in a concentration of $0.15 \mathrm{mg} / \mathrm{mL}$ with the addition of sodium carbonate at $20 \%$ After 5 minutes Folin-Ciocalteau $(2 \mathrm{~N})$ reagent was added. This reactive mixture was incubated for 10 minutes and the readings were done with a spectrophotometer of visible spectrum range of $730 \mathrm{~nm}$. The tests were run in triplicate, and for the determination of the dosing of the phenolic compounds a standard curve of gallic acid was used. The results were expressed as mg gallic acid/g dry mass.

\subsubsection{Determination of Flavonoids}

The content of flavonoids was determined by following the method described by Woisky and Salatino (1998), with little modifications. An infusion of $50 \mathrm{~g} / \mathrm{L}$ of lyophilized pennyroyal was diluted with methanol at a concentration of $1 \mathrm{mg} / \mathrm{mL}$. Chloride of aluminum at $2 \%$ and methanol were added to the solution. The mixture was kept at rest in a hotte for 30 minutes at room temperature. The readings were done with a spectrophotometer of visible spectrum range of $420 \mathrm{~nm}$. The tests were run in triplicate. For the determination of the dosing of flavonoids a standard curve of quercetin was used. The results were expressed as $\mathrm{mg}$ quercetin/g dry mass.

\subsection{Collection and Processing of the Blood Samples}

The blood samples were obtained from 18 healthy donors. All participants of the research sign the Free Informed Consent Form (TCLE). The volunteers were non-smokers and teetotalers and had not consumed any medicines that could interfere with the results of the research. These data were obtained by a questionnaire that the participants answered at the time of agreeing to take part in the research. The blood was extracted after a minimum fast of 4 hours. Venous blood was extracted by using a Vacutainer containing ethylenediaminetetraacetic acid (EDTA). The samples were immediately centrifuged at $3.000 \mathrm{rpm}$ for 10 minutes and the plasma was removed. The erythrocytes were washed three times with a saline isotonic solution $(\mathrm{NaCl}$ $0.9 \%$ ) and centrifuged once again. After the final wash, the erythrocytes were put in suspension again in the saline solution $(\mathrm{NaCl} 0.9 \%)$ and the hematocrit was diluted to $5 \%$ by following the method described by Horn et al. (2015). Each experimental group was made up of erythrocytes of the same donor, using $750 \mu \mathrm{L}$ of erythrocytes at $5 \%$

\subsubsection{Experimental Model}

Five exposures were carried out "in vitro":

> Control: $750 \mu \mathrm{L}$ erythrocytes (5\%) not exposed to $2,4-\mathrm{D}$ and treated with saline $(0.9 \% \mathrm{NaCl})$;

> $750 \mu \mathrm{L}$ of erythrocytes $(5 \%)$ exposed to $200 \mu \mathrm{L}$ of $2,4-\mathrm{D}(1.1 \mathrm{~g} / \mathrm{L})$ for $1 \mathrm{~h}$ in a water bath at $37^{\circ} \mathrm{C}$; 
$>\quad 750 \mu \mathrm{L}$ of erythrocytes $(5 \%)$ exposed to $200 \mu \mathrm{L}$ of $2,4-\mathrm{D}(1.1 \mathrm{~g} / \mathrm{L})$ for $1 \mathrm{~h}$ at $37{ }^{\circ} \mathrm{C}$ water bath and treated with $200 \mu \mathrm{L}$ of the infusion $T$. catharinensis $5 \mathrm{~g} / \mathrm{L}$ for $1 \mathrm{~h}$ at $37{ }^{\circ} \mathrm{C}$;

$>\quad 750 \mu \mathrm{L}$ of erythrocytes $(5 \%)$ exposed to $200 \mu \mathrm{L}$ of $2,4-\mathrm{D}(1.1 \mathrm{~g} / \mathrm{L})$ for $1 \mathrm{~h}$ at $37^{\circ} \mathrm{C}$ water bath and treated with $200 \mu \mathrm{L}$ of the infusion T. catharinensis $10 \mathrm{~g} / \mathrm{L}$ for $1 \mathrm{~h}$ at $37^{\circ} \mathrm{C}$;

$>\quad 750 \mu \mathrm{L}$ of erythrocytes $(5 \%)$ exposed to $200 \mu \mathrm{L}$ of $2,4-\mathrm{D}(1.1 \mathrm{~g} / \mathrm{L})$ for $1 \mathrm{~h}$ at $37{ }^{\circ} \mathrm{C}$ water bath and treated with $200 \mu \mathrm{L}$ of the infusion T. catharinensis $50 \mathrm{~g} / \mathrm{L}$ for $1 \mathrm{~h}$ at $37^{\circ} \mathrm{C}$.

After exposure erythrocytes of all groups were hemolyzed with vortexing for 10 seconds and centrifuged at 3000 rpm for 15 minutes and the supernatant stored in a freezer at $-20^{\circ} \mathrm{C}$ for subsequent analytical determinations.

\subsection{Analytical Determinations}

\subsubsection{Determination of Thiobarbituric Acid Reactive Substances (TBARS)}

TBARS were measured according to the protocol described by Stocks and Dormandy (1971). In the supernatant was added to the reaction mixture containing trichloroacetic acid (TCA) to $28 \%(\mathrm{v} / \mathrm{v})$ thiobarbituric acid (TBA) at $0.1 \mathrm{~mol} / \mathrm{L}$ and heated to $95{ }^{\circ} \mathrm{C}$. Readings were taken at $532 \mathrm{~nm}$, length in which the product formed malondialdehyde (MDA), can be measured.The results were expressed as nmol MDA/g Hb. The analysis Hemoglobin levels was performed according tothe rules of Labtest ${ }^{\circledR}$ commercial kit.

\subsubsection{Determination of Protein Carbonyls}

The analyzes of PC were carried out using the technique described by Levine (1990) adapted to erythrocytes using HEPES, 10\% TCA (v/v) hydrochloric acid (HCl) 2 N; 2,4-dinitrophenylhydrazine (DNPH) and $10 \mathrm{mM}$ sodium dodecyl sulfate $(\mathrm{SDS}), 3 \%(\mathrm{~m} / \mathrm{v})$. Readings were taken at $370 \mathrm{~nm}$ and the results were expressed as nmoles of carbonyl $/ \mathrm{mg}$ of total protein. The analysis total proteinslevels was performed according to the rules of Labtest $^{\circledR}$ commercial kit.

\subsubsection{Determination of Levels of Reduced Glutathione (GSH)}

GSH was determined by the method described by Ellman (1959) adapted to erythrocytes, is used as the reagent 5,5'-dithiobis (2-nitrobenzoic acid) (DTNB), and the reading taken at $412 \mathrm{~nm}$. The results were expressed as $\mu \mathrm{mol} \mathrm{GSH} / \mathrm{mL}$.

\subsection{Statistical Methods}

The analyzes were carried out in triplicate and results were expressed asmean \pm SEM (Standard Error of the Mean). Data from all groups for the same parameter, were submitted to analysis of variance (ANOVA) of a path followed by the Tukey-Kramer test, considering the significantly different means with a $\mathrm{P}<0.05$.

\section{Results}

According to the table 1 , in the infusion of $T$. catharinensis $50 \mathrm{~g} / \mathrm{L}$ were found $64,6764.67 \pm 2.14 \mathrm{mg} / \mathrm{g}$ of total phenolic compounds and $15 \pm 0.315 \mathrm{mg} / \mathrm{g}$ of flavonoids.

Table 1. Quantification of total phenolic compounds and flavonoids present in the infusion of T. catharinensis 50 $\mathrm{g} / \mathrm{L}$. The results are expressed as mean \pm standard deviation

\begin{tabular}{lll}
\hline Sample & Total phenolic compounds (mg/g) & Flavonoids (mg/g) \\
\hline Infusion of $\boldsymbol{T}$. catharinensis $\mathbf{( 5 0} \mathbf{~ g / L ) ~}$ & $64.67 \pm 2.14$ & $15 \pm 0.315$ \\
\hline
\end{tabular}

The infusion of cobrina promoted an increase in the level of lipid peroxidation in all the concentrations tested (Figure 1). Figure 2 shows that the protein carbonylation levels were higher in groups erythrocytes exposed to 2,4-D and treated with infusion of cobrina in dilutions of 10 and $50 \mathrm{~g} / \mathrm{L}$. In addition, Figure 3 shows that GSH increased in the group of erythrocytes treated with 2,4-D, and further increased in the group of exposed erythrocytes exposed to 2,4-D and treated with infusion of cobrina in concentration of $50 \mathrm{~g} / \mathrm{L}$. 


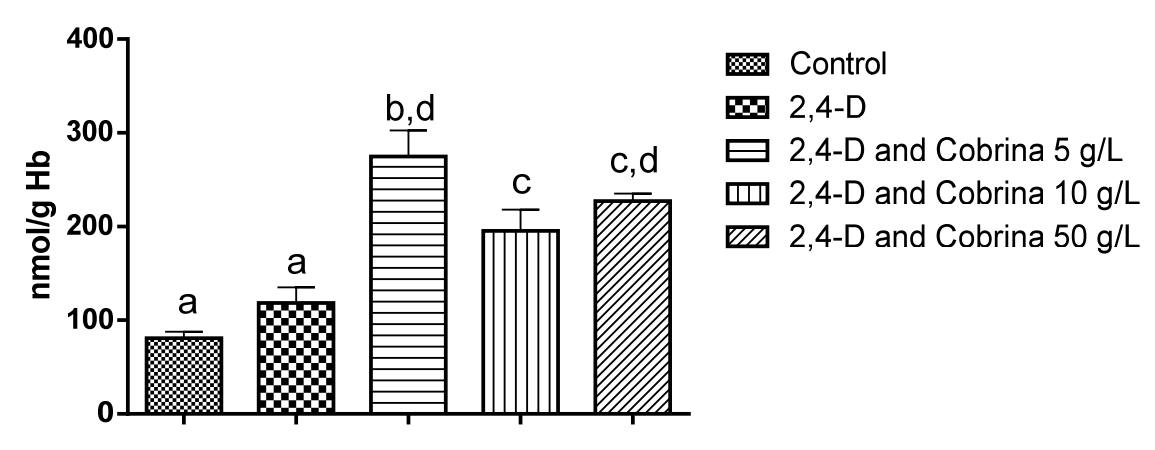

Figure 1. TBARS (nmol MDA/mg Hb) levels in human erythrocytes

Note. Different letters represent significantly different statistics, considering a $\mathrm{P}<0.05$.

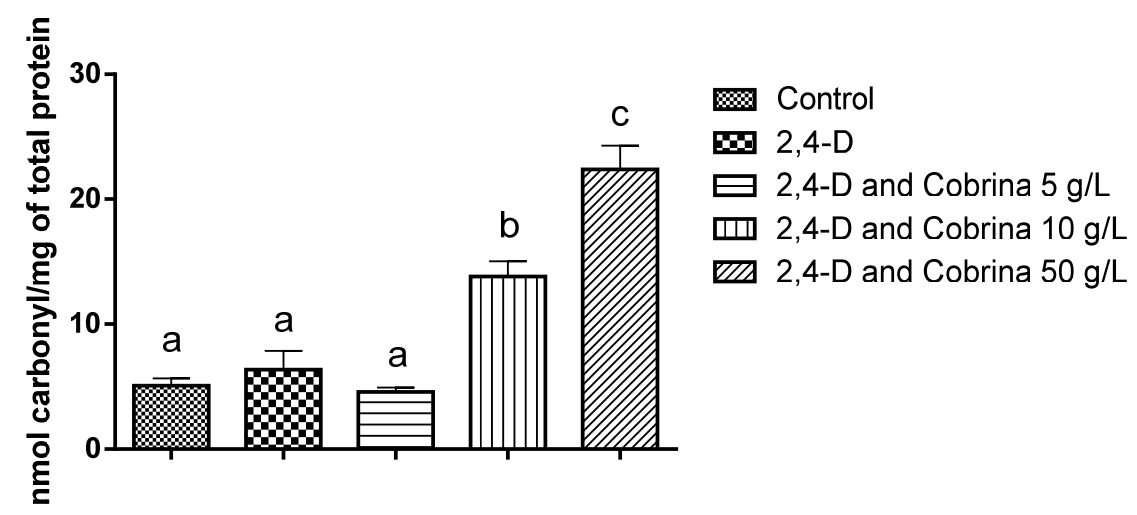

Figure 2. Carbonyl protein levels (nmol carbonyl $/ \mathrm{mg}$ total protein) in human erythrocytes

Note. Different letters represent significantly different statistics, considering a $\mathrm{P}<0.05$.

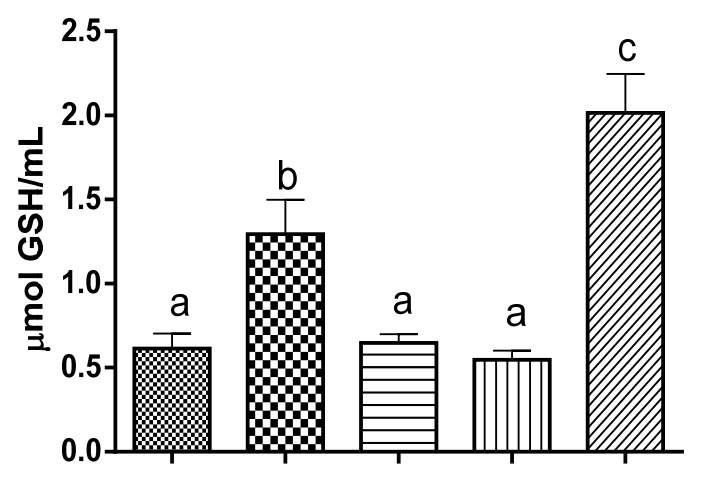

Control

2,4-D

๑2,4-D and Cobrina $5 \mathrm{~g} / \mathrm{L}$

때 2,4-D and Cobrina $10 \mathrm{~g} / \mathrm{L}$

2,4-D and Cobrina $50 \mathrm{~g} / \mathrm{L}$

Figure 3. GSH ( $\mu \mathrm{mol} \mathrm{GSH} / \mathrm{mL})$ levels in human erythrocytes

Note. Different letters represent significantly different statistics, considering a $\mathrm{P}<0.05$.

\section{Discussion}

4.1 Levels of Total Phenolic Compounds and Flavonoids in the Infusion of T. catharinensis $(50 \mathrm{~g} / \mathrm{L})$

The formation of reactive species occurs naturally in the human body, as a result of the need of aerobic organisms to oxidize cells for the production of a high amount of energy. Reactive species play diverse roles, 
such as production of energy, phagocytosis, regulation of cell growth, intercell-signalling and synthesis of important biological substances. Nevertheless, the excess of reactive species can be responsible for a series of damaging effects, such as peroxidation of membrane lipids; attack to proteins of tissues and of membranes, enzymes, carbohydrates and deoxyribonucleic acid (DNA) by damaging membranes and causing them to lose fluidity, which can lead to the appearance of cancer as a result of the alterations in DNA; early aging, cardiovascular degenerative and neurological diseases; haemorhagic stroke and cataract, among other sicknesses (Barreiros et al., 2006; Rathee et al., 2006; Alves et al., 2010). This excess of reactive species is fought by antioxidants, either endogenous or exogenous (absorbed from food). Among exogenous antioxidants, phenolic compounds are of note, especially flavonoids, which originate in natural products, owing to the fact that such compounds show resonance after intervening in the fight against free radicals, this way having a determined stability, which allows them to retain the unpaired electron without causing any damage to the cell structure (Soares, 2002; Barreiros et al., 2006; Sousa de Sá et al., 2012). According to Sousa et al. (2007), phenolic compounds are divided into the following categories: simple phenols, phenolic acids (derivatives of benzoic acid and cinnamic acid), coumarins, flavonoids, stilbenes, condensed and hydrolyzable tannin, lignin and lignans. Therefore, from the data in Tableland the assertions already evidenced, it is possible to conclude that the infusion of T. catharinensis $(50 \mathrm{~g} / \mathrm{L})$ contains $64.67 \pm 2.14 \mathrm{mg} / \mathrm{g}$ of phenolic compounds, and that $23.19 \%$ of them are flavonoids, which can, for that reason, have significant antioxidant effect on erythrocytes exposed to a xenobiotic like 2,4-D.

\subsection{Assessment of the Oxidative Stress Markers of the Infusion of Tabernaemontana catharinensis in Erythrocytes Exposed in vitro to 2,4-D}

According to Figure 1, the infusion of cobrina favors an increase in the level of lipid peroxidation in all the dilutions tested, and an increase in carbonylated proteins in concentrations of 10 and $50 \mathrm{~g} / \mathrm{L}$ (Figure 2), indicating that those infusions were more toxic than the exposure to 2,4-dichlorophenoxyacetic. The expected result of this research was confronted to the result of the research by Boligon et al. (2014), which proved that the gross extract and fractions of $T$. catharinensis can be considered efficient for the prevention of diseases associated with oxidative stress because of their antioxidant capacity. The result was corroborated with Boligon and Athaide (2012), who, in spite of having found antioxidant alkaloids in the hydroalcoholic extract of $T$. catharinensis, also found cytotoxic effects in shrimps. Furthermore, according to Aslan et al. (2000) the erythrocyte is a spot where there is much generation of reactive species, owing to the high concentration of unsaturated fats in its membrane, a rich supply of oxygen and high concentration of hemoglobin that can promote the oxidation processes. So, it is possible that the infusion of cobrina has stimulated another way of generation of reactive oxygen species (ROS) in the erythrocyte, with the consequent increase increase in damage to fats and proteins.

In order to further elucidate the above question, and assessment was made of the effect of the infusion of cobrina on the main endogen antioxidant agent, a glutathione (GSH), and it was found that there was an increase in the levels of this biological marker in the treatment with infusion of cobrina in the concentration of $50 \mathrm{~g} / \mathrm{L}$ (Figure 3). This result may have occurred in response to a strong production of reactive species favored by the infusion of cobrina itself in this concentration, which also generated and increase in thiobarbituric and reactive substances (TBARS) and in protein carbonyl, and culminated in the activity of the glutathione reductase enzyme (GR), which is responsible for the conversion of oxidized glutathione (GSSH) into GSH (Huber et al., 2008), so as to increase the antioxidant protection. On the other hand, the increase in GSH probably occurred in order to keep the redox balance, bearing in mind that such antioxidant agent plays important roles in the elimination of xenobiotics and in the protection of the cells from the oxidative stress (Huber et al., 2008; Lushchak, 2012), It is expected that in a longer time of exposition there might be a reversion of the results of this research, with a higher neutralization of 2,4-D by the action of glutathione transferase (GST), which bonds GSH to xenobiotics, and also an activation of glutathione peroxidase (GPX) which is responsible for catalyzing a reaction of $2 \mathrm{GSH}$ with hydrogen peroxide, generating oxidized glutathione and 2 molecules of water (Barbosa et al., 2010).

\section{Conclusion}

This research proved that the infusion of Tabernaemontana catharinensis promotes an increase in the damage generated by oxidative stress in erythrocytes exposed to the herbicide 2,4-D. Nonetheless, it is evident that it will be important to continue conducting this type of in vitro research on $T$. catharinensis and different times of incubation so as to confirm the risk-benefit ratio of the massive use of 2,4-D. 


\section{References}

Alves, C. Q., David, J. M., David, J. P., Bahia, M. V., \& Aguiar, R. M. (2010). Métodos para determinação de atividade antioxidante in vitro em substratos orgânicos. Química Nova, 33, 2202-2210. http://dx.doi.org/10.1590/S0100-40422010001000033

Aslan, M., Thornley, B. D., \& Freeman, B. A. (2000). Reactive species in sickle cell disease. Annals New York Academy of Sciences. New York, 899, 375-391. http://dx.doi.org/10.1111/j.1749-6632.2000.tb06201.x

Barbosa, K. B. F., Costa, N. M. B., Alfenas, R. C. G., De Paula, S. O., Minim, V. P. R., \& Bressan, J. (2010). Estresse oxidativo: Conceito, implicações e fatores modulatórios. Revista de Nutrição Campinas, 23, 629-643. http://dx.doi.org/10.1590/S1415-52732010000400013

Barreiros, A. L. B. S., David, J. M., \& David, J. P. (2006). Estresse oxidativo: Relação entre geração de espécies reativas e defesa do organismo. Química Nova, 29, 113-123. http://dx.doi.org/10.1590/S0100-40422006000100021

Boligon, A. A., \& Athayde, M. L. (2012). Phytochemical investigation and cytotoxic properties of Tabernaemontana catharinensis A. DC. cultivated in Brazil. Research Journal of Phytochemistry, 6, 127-131. http://dx.doi.org/10.3923/rjphyto.2012.127.131

Boligon, A. A., De Freitas, R. B., De Brum, T. F., Piana, M., Belke, B. V., Da Rocha, J. B. T., \& Athayde, M. L. (2013). Phytochemical constituents and in vitro antioxidant capacity of Tabernaemontana catharinensis A. DC. Free Radicals and Antioxidants, 3, 77-80. http://dx.doi.org/10.1016/j.fra.2013.05.007

Boligon, A. A., Piana, M., Kubiça, T. F., Mario, D. N., Dalmolin, T. V., Bonez, P. C., ... Athayde, M. L. (2015). HPLC analysis and antimicrobial, antimycobacterial and antiviral activities of Tabernaemontana catharinensis A. DC. Journal of Applied Biomedicine, 13, 7-18. http://dx.doi.org/10.1016/j.jab.2014.01.004

Boligon, A. A., Piana, M., Schawnz, T. G., Pereira, R. P., Rocha, J. B., \& Athayde, M. L. (2014). Chromatographic analysis and antioxidant capacity of Tabernaemontana catharinensis. Natural Product Communications, 9, 61-64.

Bortolozi, A., Duffard, R., \& Evangelista de Duffard, A. M. (2003). Asymmetrical development of the monoamine systems in 2, 4-dichlorophenoxyacetic acid treated rats. NeuroToxicology, 24, 149-157. http://dx.doi.org/10.1016/S0161-813X(02)00156-0

Bortolozi, A., Evangelista de Duffard, A. M., Duffard, R., \& Antonelli, M. (2004). Effects of 2, 4-dichlorophenoxyacetic acid exposure on dopamine D2-like receptors in rat brain. Neurotoxicology Teratology, 26, 599-605. http://dx.doi.org/10.1016/j.ntt.2004.04.001

Bukowska, B. (2006). Toxicity of 2, 4-Dichlorophenoxyacetic Acid-Molecular Mechanisms. Polish Journal of Environmental Studies, 15, 365-374.

Chandra, S., \& Mejia, E. G. (2004). Polyphenolic compounds, antioxidant capacity and quinone reductase activity of na aqueous extract of Ardisia compressa in comparison to Mate (Ilex paraguariensis) and Green (Camellia sinensis) Teas. Journal of Agricultural and Food Chemistry, 52, 3583-3589. http://dx.doi.org/10.1021/jf0352632

De Sá, P. G. S., Guimarães, A. L., De Oliveira, A. P., De Siqueira Filho, J. A., Fontana, A. P., Damasceno, P. K. F., ... Almeida, J. R. G. S. (2012). Fenóis totais, flavonoides totais e atividade antioxidante de Selaginella convoluta (Arn.) Spring (Selaginellaceae). Revista de Ciências Farmacêuticas Básica e Aplicada, 33, 561-566.

Ellman, G. L. (1959). Tissue sulfhydryl groups. Archives Biochemistry and Biophysics, 82, $70-77$. http://dx.doi.org/10.1016/0003-9861(59)90090-6

Garcia, G., Tagliaferro, P., Ferri, A., Evangelista de Duffard, A. M., Duffard, R., \& Brusco, A. (2004). Study of tyrosine hydroxylase immunoreactive neurons in neonate rats lactationally exposed to 2,4-dichlorophenoxyacetic acid. NeuroToxicology, 25, 951-957. http://dx.doi.org/10.1016/j.neuro.2004. 05.004

Guidoti, D. G. G., Guidoti, D. T., Rocha, C. L. M. S. C., \& Mourão, K. S. M. (2015). Morphoanatomic characterization of the stem and the leaf of Tabernaemontana catharinensis A. DC (Apocynaceae) and antimutagenic activity of its leaves. Revista Brasileira de Plantas Medicinais, 17, 667-678. http://dx.doi.org/10.1590/1983-084X/14_077 
Horn, R. C., Soares, J. C., Mori, N. C., Gelatti, G. T., Manfio, C. E., Golle, D. P., ... Oliveira, C. (2015). Antioxidant Effect of Physalis Peruviana Fruit Aqueous Extract. Journal of Agricultural Science, 7, 137-143. http://dx.doi.org/10.5539/jas.v7n12p137

Huber, P. C., Almeida, W. P., \& De Fátima, A. (2008). Glutationa e Enzimas Relacionadas: papel biológico e importância em processos patológicos. Química Nova, 31, 1170-1179. http://dx.doi.org/10.1590/S0100-40422008000500046

Levine, R. L., Garland, D., Amici, A., Climent, I., Lenz, A. G., Ahn, B. W., ... Stadtman, E. R. (1990). Determination of carbonyl contente in oxidatively modified proteins. Methods in Enzymology, 186, 464-478. http://dx.doi.org/10.1016/0076-6879(90)86141-H

Lushchak, V. I. (2012). Glutathione homeostasis and functions: Potential targets for medical interventions. Journal of Amino Acids, 2012, 1-26. http://dx.doi.org/10.1155/2012/736837

Murussi, C., Horn, R. C., Santi, A., Clasen, B. E., Reis, G., Souza, D., ... Loro, V. L. (2014). Changes in oxidative markers, endogenous antioxidants and activity of the enzyme acetylcholinesterase in farmers exposed to agricultural pesticides-A pilot study. Ciência Rural, 44, 1186-1193. http://dx.doi.org/10.1590/0103-8478cr20130516

Nicola, C., Salvador, M., Gower, A. E., Moura, S., \& Echeverrigaray, S. (2013). Chemical constituents antioxidant and anticholinesterasic activity of Tabernaemontana catharinensis. The Scientific World Journal, 2013. http://dx.doi.org/10.1155/2013/519858

Pereira, C. G., Leal, P. F., Sato, D. N., \& Meireles, A. A. (2005). Antioxidant and antimycobacterial activities of Tabernaemontana catharinensis extracts obtained by supercritical $\mathrm{CO}_{2}+$ cosolvent. Journal of Medicinal Food, 8, 533-538. http://dx.doi.org/10.1089/jmf.2005.8.533

Rathee, J. S., Hassarajani, S. A., \& Chattopadhyay, S. (2006). Antioxidant activity of Mammea longifolia bud extracts. Food Chemistry, 99, 436-443. http://dx.doi.org/10.1016/j.foodchem.2005.08.020

Saghir, S. A., Marty. M. S., Zablotny, C. L., Passage, J. K., Perala, A. W., Bus, J. S., ... Hammond, L. (2013). Life-stage-, sex-, and dose-dependent dietary toxicokinetics and relationship to toxicity of 2,4-dichlorophenoxyacetic acid (2,4-D) in rats: Implications for toxicity test dose selection, design, and interpretation. Toxicological Sciences, 136, 294-307. http://dx.doi.org/10.1093/toxsci/kft212

Soares, S. E. (2002). Ácidos fenólicos como antioxidantes. Revista de Nutrição, 15, 71-81. http://dx.doi.org/10.1590/S1415-52732002000100008

Song, Y. (2014). Insight into the mode of action of 2,4-dichlorophenoxyacetic acid (2,4-D) as an herbicide. Journal of Integrative Plant Biology, 56, 106-113. http://dx.doi.org/10.1111/jipb.12131

Sousa, C. M. M., Silva, H. R., Vieira Jr, G. M., Ayres, M. C. C., Costa, C. L. S., Araújo, D. S., ... Chaves, M. H. (2007). Fenóis totais e atividade antioxidante de cinco plantas medicinais. Química Nova, 30, 351-355. http://dx.doi.org/10.1590/S0100-40422007000200021

Stocks, J., \& Dormandy, T. L. (1971). The autooxidation of human red cell lipids induced by hydrogen peroxide. British Journal of Haematology, 20, 95-111. http://dx.doi.org/10.1111/j.1365-2141.1971.tb00790.x/citedby

Woisky, R. G., \& Salatino, A. (1998). Analysis of própolis: Some parameters and procedures for chemical quality control. Journal of Apicultural Research, 37, 99-105. http://dx.doi.org/10.1080/00218839. 1998.11100961

\section{Copyrights}

Copyright for this article is retained by the author(s), with first publication rights granted to the journal.

This is an open-access article distributed under the terms and conditions of the Creative Commons Attribution license (http://creativecommons.org/licenses/by/4.0/). 